\title{
Controversial Hohokam handstones from the Salt River Valley, Arizona
}

Crushers or manoplas? A comparative approach

Les énigmatiques objets en pierre portables hohokam de la Salt River Valley, Arizona. Broyeurs ou manoplas? Une approche comparative

Enigmáticos objetos hohokam portátiles en piedra del valle del Río Salado, Arizona. ¿Trituradoras o manoplas? Un acercamiento comparativo

\section{Eric Taladoire}

\section{(2) OpenEdition}

\section{Journals}

Electronic version

URL: https://journals.openedition.org/jsa/18721

DOI: $10.4000 /$ jsa. 18721

ISSN: 1957-7842

\section{Publisher}

Société des américanistes

\section{Printed version}

Date of publication: 15 December 2020

Number of pages: 203-229

ISSN: 0037-9174

Electronic reference

Eric Taladoire, "Controversial Hohokam handstones from the Salt River Valley, Arizona", Journal de la Société des américanistes [Online], 106-2 | 2020, Online since 30 December 2020, connection on 16 September 2022. URL: http://journals.openedition.org/jsa/18721 ; DOI: https://doi.org/10.4000/jsa. 18721 


\title{
Controversial Hohokam handstones from the Salt River Valley, Arizona
}

\section{Crushers or manoplas? A comparative approach}

\author{
Eric TALADOIRE *
}

The presence and function in several Hohokam sites of controversial objects, currently described as handstones or crushers, remains an unsolved matter. Their morphology recalls similar Mesoamerican pieces, the manoplas, generally considered to be related to the ballgame. The identification of ballcourts in Hohokam sites has long been a controversial issue, but is now generally agreed on. This paper does not aim to resolve this interrogation, but rather to call attention to a problematic aspect of relationships between Mesoamerica and Oasisamerica. [Keywords: ballgame, Hohokam, manoplas, crushers, Tepiman connection.]

Les énigmatiques objets en pierre portables hohokam de la Salt River Valley, Arizona. Broyeurs ou manoplas? Une approche comparative. La présence et la fonction, sur plusieurs sites Hohokam, d'objets controversés, généralement qualifiés de broyeurs ou de pierres portables, demeurent un objet de discussions. Leur morphologie rappelle celle d'objets mésoaméricains, les manoplas, souvent associés au jeu de balle. L'identification de terrains de jeu de balle hohokam, longtemps controversée, est désormais acceptée. Ce travail ne cherche pas à résoudre la question, mais plutôt à attirer l'attention sur un aspect problématique des relations entre la Mésoamérique et l'Oasisamérique. [Mots-clés : jeu de balle, Hohokam, manoplas, broyeur, connexion tepiman.]

Enigmáticos objetos hohokam portátiles en piedra del valle del Río Salado, Arizona. ¿Trituradoras o manoplas? Un acercamiento comparativo. La presencia y la función, en varios sitios hohokam, de ciertos objetos polémicos, generalmente calificados de trituradoras o de manoplas queda por discutirse. Su morfología recuerda la de otros objetos mesoamericanos, las manoplas, frecuentemente asociados al juego de pelota. La identificación de canchas de juego hohokam, previamente discutida, queda ahora aceptada. Este trabajo no busca resolver la pregunta, pero sólo llamar la atención sobre un aspecto problemático de las relaciones entre Mesoamérica y Oasisamérica. [Palabras clave: juego de pelota, Hohokam, manoplas, trituradoras, conexión tepiman.]

* Emeritus Professor, UMR 8096 "Archéologie des Amériques," Université Paris 1Panthéon-Sorbonne [taladoire@yahoo.fr]. 
The Hohokam civilization in Arizona has long been the focus of intense attention for its complexity. Among its most important features, we can mention the elaborate settlement pattern associated with large-scale irrigation systems, intensive agricultural practices and long-distance exchange systems mainly with Mesoamerica. Turquoise, macaws and copper bells are only a few examples of these marketable products that confirm the intensity and the antiquity of such practices. Comparative studies and intensive research have provided a quite comprehensive insight into the Hohokam civilization and its external connections.

Even so, some aspects cannot yet be properly interpreted, in the absence of written documents or contextual evidence. Such is the case for a small quantity of lithic artefacts from Colonial (800-950) or Sedentary (950-1150) sites, currently designated as crushers or handstones, due to their morphology (Table 1). In the light of unconvincing former interpretations, the present study, based on a comparison with equally controversial Mesoamerican objects usually related to the ballgame, aims to draw attention to this specific aspect of the relationships between Mesoamerica and the Southwest.

\begin{tabular}{|c|c|c|c|c|c|c|c|c|c|}
\hline & $\begin{array}{l}\text { Number, } \\
\text { reference }\end{array}$ & Provenience & $\mathbf{L}$ & $\mathbf{W}$ & $\mathbf{T}$ & $\begin{array}{c}\text { Handle } \\
\text { (cm) }\end{array}$ & $\begin{array}{l}\text { Hole } \\
\text { (cm) }\end{array}$ & We & Other \\
\hline 1 & $\begin{array}{l}\text { 61/599 ASU. } \\
\text { Wilcox and } \\
\text { Sternberg 1983, } \\
\text { fig. 5.1, tab. 5.3, } \\
\text { Midvale coll. }\end{array}$ & $\begin{array}{l}\text { Lower Salt } \\
\text { River Valley }\end{array}$ & 16.9 & 15.4 & 8.6 & $2.3 \times 2.7$ & $4.2 \times 4.76$ & 1.828 & $\begin{array}{l}\text { Incised } \\
\text { motifs? }\end{array}$ \\
\hline 2 & $\begin{array}{l}\text { 67/432 ASU. } \\
\text { Wilcox and } \\
\text { Sternberg 1983, } \\
\text { fig. 5.1, tab. 5.3; } \\
\text { Midvale coll. }\end{array}$ & $\begin{array}{l}\text { Lower Salt } \\
\text { River Valley }\end{array}$ & 12.3 & 8.3 & 5.1 & $2.3 \times 2.7$ & $0.8 \times 0.8$ & 0.58 & \\
\hline 3 & $\begin{array}{l}\text { 68/2507 ASU. } \\
\text { Wilcox and } \\
\text { Sternberg 1983, } \\
\text { fig. 5.1, tab. 5.3. } \\
\text { Midvale coll. }\end{array}$ & $\begin{array}{l}\text { Lower Salt } \\
\text { River Valley, } \\
\text { Los Hornos }\end{array}$ & 21.6 & 13 & 13 & $4.4 \times 4.5$ & $2.2 \times 3.6$ & 1.99 & \\
\hline 4 & $\begin{array}{l}\text { 61/63 ASU. } \\
\text { Wilcox and } \\
\text { Sternberg 1983, } \\
\text { fig. 5.1, tab. 5.3. } \\
\text { Midvale coll. }\end{array}$ & $\begin{array}{l}\text { Lower Salt } \\
\text { River Valley }\end{array}$ & 12.7 & 18.4 & 9 & $1.9 \times 2.6$ & $2.4 \times 2.9$ & 2.44 & \\
\hline 5 & $\begin{array}{l}\text { 68/250 ASU. } \\
\text { Wilcox and } \\
\text { Sternberg 1983, } \\
\text { fig. 5.1, tab. 5.3. } \\
\text { Midvale coll. }\end{array}$ & $\begin{array}{l}\text { Lower Salt } \\
\text { River Valley, } \\
\text { Los Hornos }\end{array}$ & 25.1 & 21.4 & 11.5 & $4.2 \times 4.8$ & $5.6 \times 8$ & 4.54 & $\begin{array}{c}\text { Incised } \\
\text { motifs }\end{array}$ \\
\hline
\end{tabular}




\begin{tabular}{|c|c|c|c|c|c|c|c|c|c|}
\hline 6 & $\begin{array}{l}\text { 6125 ASM. } \\
\text { Wilcox and } \\
\text { Sternberg 1983, } \\
\text { fig. 5.1, tab. 5.3 }\end{array}$ & $\begin{array}{l}\text { Lower Salt } \\
\text { River Valley }\end{array}$ & 20 & 18.7 & 7 & $3.9 \times 4.5$ & & 2.97 & $\begin{array}{l}\text { Reworked } \\
\text { metate }\end{array}$ \\
\hline 7 & $\begin{array}{l}\text { Present loca- } \\
\text { tion unknown. } \\
\text { Haury } 1945, \\
\text { p. } 137, \text { fig. } 81 \text {, } \\
\text { plate } 57\end{array}$ & $\begin{array}{l}\text { Gila-Salt, } \\
\text { Los Muertos }\end{array}$ & 23 & 15.2 & 12.7 & & 5 & 4.5 & $\begin{array}{l}\text { Colonial, } \\
\text { andesite or } \\
\text { rhyolite }\end{array}$ \\
\hline 8 & $\begin{array}{c}\text { Present loca- } \\
\text { tion unknown. } \\
\text { Haury } 1945, \\
\text { p. } 137, \text { fig. } 81, \\
\text { plate } 57\end{array}$ & $\begin{array}{l}\text { Gila-Salt, } \\
\text { Los Muertos }\end{array}$ & & 5.2 & & & & & $\begin{array}{l}\text { Discoid } \\
\text { crusher } \\
\text { andesite or } \\
\text { rhyolite }\end{array}$ \\
\hline 9 & $\begin{array}{c}\text { Present loca- } \\
\text { tion unknown. } \\
\text { Haury } 1945, \\
\text { p. } 137\end{array}$ & $\begin{array}{l}\text { Gila-Salt, } \\
\text { Los Muertos }\end{array}$ & & & & & & & $\begin{array}{l}\text { Fragment, } \\
\text { andesite or } \\
\text { rhyolite }\end{array}$ \\
\hline 10 & $\begin{array}{c}\text { Present loca- } \\
\text { tion unknown. } \\
\text { Haury } 1945, \\
\text { p. } 137\end{array}$ & $\begin{array}{l}\text { Gila-Salt, } \\
\text { Los Muertos }\end{array}$ & & & & & & & $\begin{array}{l}\text { Fragment, } \\
\text { andesite or } \\
\text { rhyolite }\end{array}$ \\
\hline 11 & $\begin{array}{l}\text { Present loca- } \\
\text { tion unknown. } \\
\text { Moorehead 1906, } \\
\text { fig. 27d; } \\
\text { Haury } 1945\end{array}$ & $\begin{array}{l}\text { Salt River } \\
\text { Valley }\end{array}$ & & & & & & & $\begin{array}{l}\text { Spheroid } \\
\text { clay- } \\
\text { crushing } \\
\text { stone }\end{array}$ \\
\hline 12 & $\begin{array}{l}\text { Present loca- } \\
\text { tion unknown. } \\
\text { Moorehead 1906, } \\
\text { fig. 27d; } \\
\text { Haury } 1945\end{array}$ & $\begin{array}{l}\text { Salt River } \\
\text { Valley }\end{array}$ & & & & & & & $\begin{array}{l}\text { Spheroid, } \\
\text { handle, } \\
\text { clay- } \\
\text { crushing } \\
\text { stone }\end{array}$ \\
\hline 13 & $\begin{array}{c}254497 . \\
\text { Fewkes } 1912, \\
\text { p. 129, plate 66a; } \\
\text { Haury } 1945\end{array}$ & Casa Grande & & & & & & & $\begin{array}{c}\text { Sedentary/ } \\
\text { Classic. } \\
\text { Small, } \\
\text { worn. } \\
\text { Lava } \\
\end{array}$ \\
\hline 14 & $\begin{array}{c}254496 . \\
\text { Fewkes } 1912, \\
\text { p. 129, plate } 66 \mathrm{~b} ; \\
\text { Haury } 1945\end{array}$ & Casa Grande & 60 & & & & & & $\begin{array}{l}\text { Sedentary/ } \\
\text { Classic. } \\
\text { Lava }\end{array}$ \\
\hline 15 & $\begin{array}{l}\text { Present loca- } \\
\text { tion unknown. } \\
\text { Haury } 1945, \\
\text { p. } 169, \text { fig. } 107 \text {, } \\
\text { plate } 81 \mathrm{~h}\end{array}$ & $\begin{array}{l}\text { Gila-Salt, } \\
\text { Las Acequías }\end{array}$ & 23 & & & & 2.54 & & $\begin{array}{l}\text { Double } \\
\text { perfora- } \\
\text { tion Lava }\end{array}$ \\
\hline
\end{tabular}

Table 1 - Documented handstones from Arizona

(L: length, W: width, T: thickness, dimensions in cm; We: weight in $\mathrm{kg}$ ) 


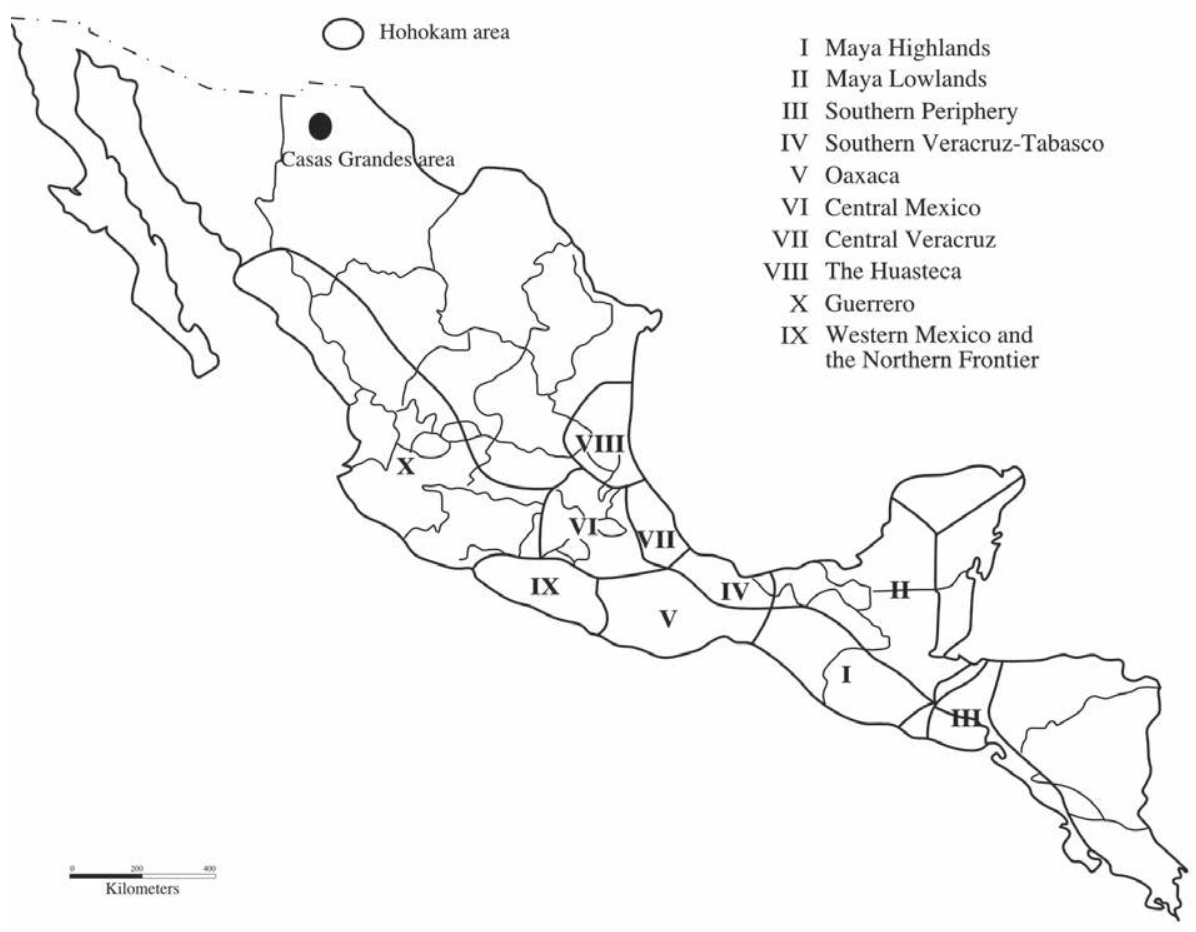

Fig. 1 - Schematic map (drawing by S. Éliès)

The presence of ballcourts in Arizona has long been a controversial issue, first in relation to their identification as ballcourts and then about their origin. Wilcox and Sternberg's (1983) publication amply confirms their existence and their similarity with their Mesoamerican counterparts. Recent research in northwestern Mexico has confirmed the presence of numerous ballcourts in the intermediate areas, even if Wilcox's hypothesis of a Tepiman connection (1986) remains a matter of discussion (Figure 1). But we may wonder why only the game and its architectural setting were adopted to the exclusion of many other features associated with the Mesoamerican ballgame, such as markers, sculptures or ritual paraphernalia? Were they introduced too, or discarded as irrelevant?

In the report of his Casa Grande excavations, Fewkes (1912, plate 66, $n^{\circ} 254496$ and 254497) published a photo of two badly eroded, unidentified objects, which he passingly calls "problematical stone objects" (Figure 2a; Table $\left.1, n^{\circ} 13,14\right)$. He specifically differentiates them from mortars and other grinding stones, partly because of their handles.

It is all the more surprising that, only a few years earlier, he had been confronted with five morphologically similar pieces from the Dehesa collection (Figure 2b), 

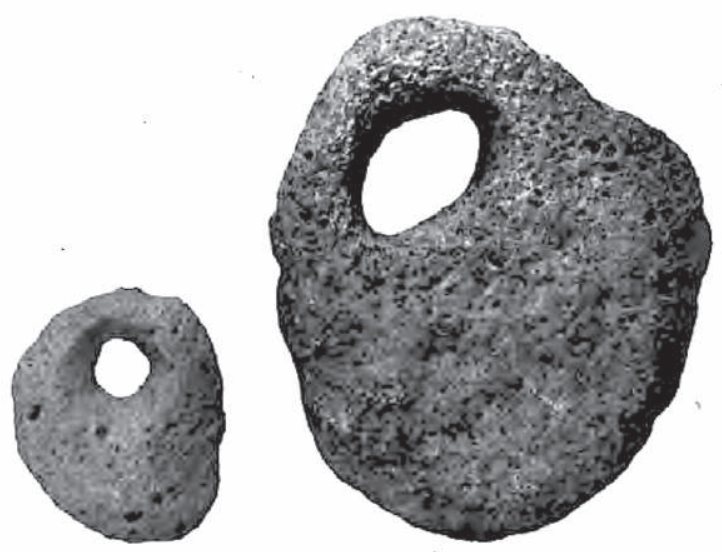

Fig. 2a-Worn handstones from Casa Grande (after Fewkes 1912)

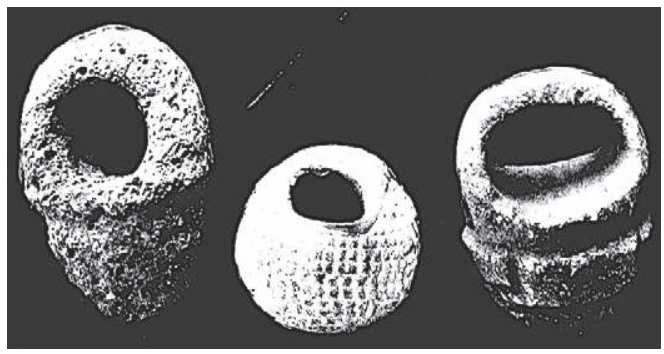

Fig. $2 b$ - Three handstones from the Dehesa collection (after Fewkes 1907)

in Veracruz (Fewkes 1907, p. 266). Of course, the general aspect of both sets of objects differs somewhat, between the badly eroded plain Hohokam handstones and the decorated pieces from Veracruz (Table 2, $\left.\mathrm{n}^{\circ} 1,2,3,4,5\right)$. So did the investigation context, all the more since, at the time, such items could not be related to any known activity.

In the following years, several similar items were discovered or excavated at other Hohokam sites (Figure 3). Most of them proceed from Hohokam ballcourt sites (Los Hornos, Los Muertos, Casa Grande), and from the lower Salt River Valley, where ballcourts are numerous. According to Wilcox and Sternberg (1983, p. 64-65, fig. 5-1, tab. 5.3),

others are reported from the Salt River Valley (Moorehead 1906) and Los Muertos (Haury 1945). They have been interpreted as clay crushers, but the facts - that they are so rare, vary greatly in size, and show no signs of battering and pounding - do not support this view. The smallest stone in figure 5.1 does have a greatly battered end. The rest are morphologically identical to the simpler ballgame handstones 


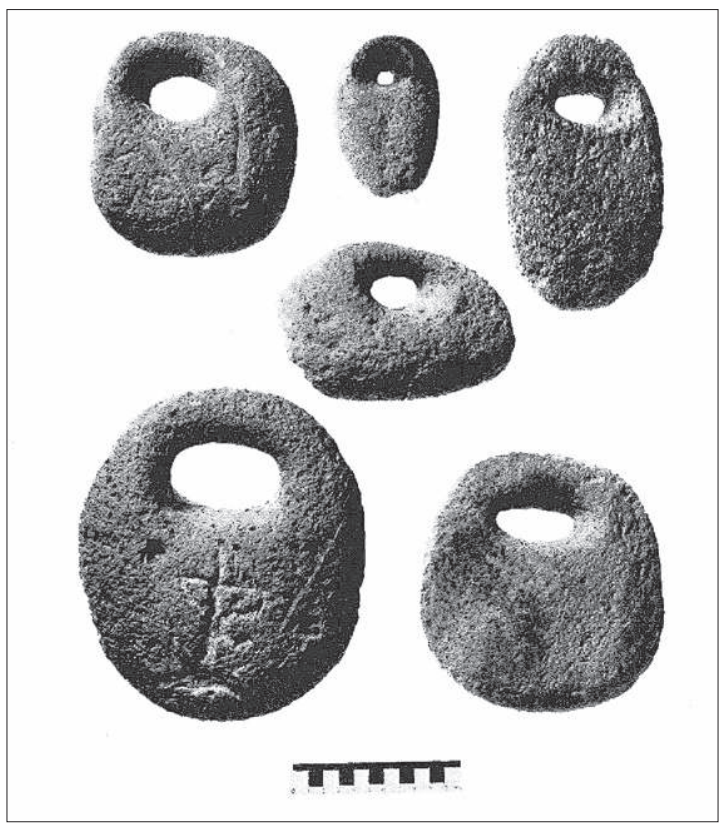

Fig. 3 - Six handstones from the Salt River Valley

(from Wilcox and Sternberg 1983, fig. 5-1, after a reference not provided by the authors), $\mathrm{n}^{\circ} 1$ to 6 , Table 1

pictured by Borhegyi $(1961$, p. 136; 1964) and we suggest they may have been used similarly in the Southwest.

To be more precise (Table 1), six handstones, mostly from the Frank Midvale collections, belong to the Arizona State University ( $\left.{ }^{\circ} 1,2,3,4,5,6\right)$. Fewkes's items probably belong to this set. Moorehead (1906, fig. 27d) found at least two items in a site from the lower Salt River Valley (Table 1, $\mathrm{n}^{\circ} 11$ and 12), and Haury (1945, p. 137, fig. 81, plate 57) found two more and two fragments at the Los Muertos site $\left(n^{\circ} 7,8,9,10\right.$; Figure 4$)$. Even if he calls them crushers, he considers them unique, because they do not present traces of grinding use, at least from a superficial examination. He compares them with Fewkes's and Moorehead's items. A "ballplayer paddle" from Mesa Grande belongs to the collections of the Arizona Museum of Natural History. It could be one of the pieces found by Moorehead. To be complete, Haury (1945, p. 169, fig. 107) also mentions a double-perforated stone from Las Acequías, which he describes as similar to the Los Muertos crushers, in spite of its double perforation (Table 1, $\mathrm{n}^{\circ}$ 15; Figure 5). According to the different authors, the list might be longer, but we did not encounter any more recent reference. This is all the more surprising considering the density of well-excavated sites. 


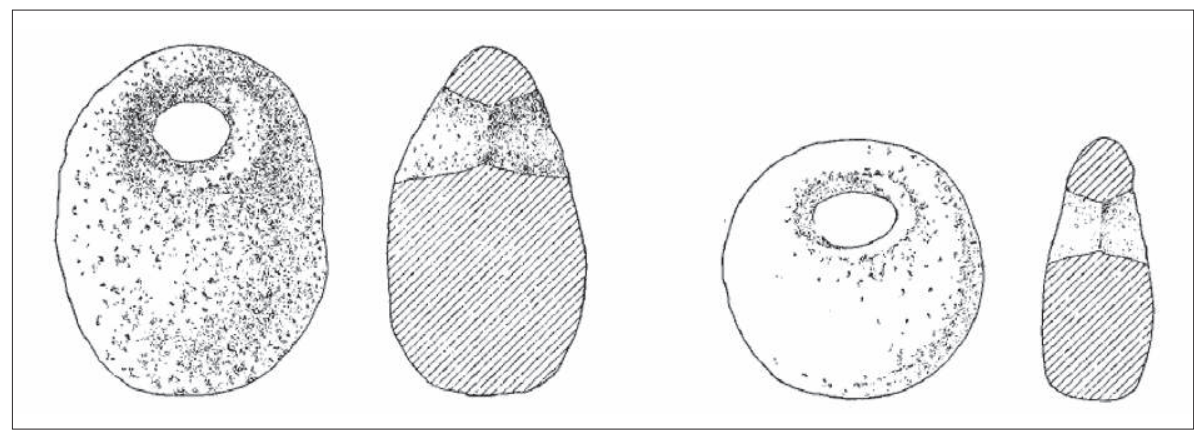

Fig. 4 - Handstones from Los Muertos (nº 7, 8), after Haury 1945

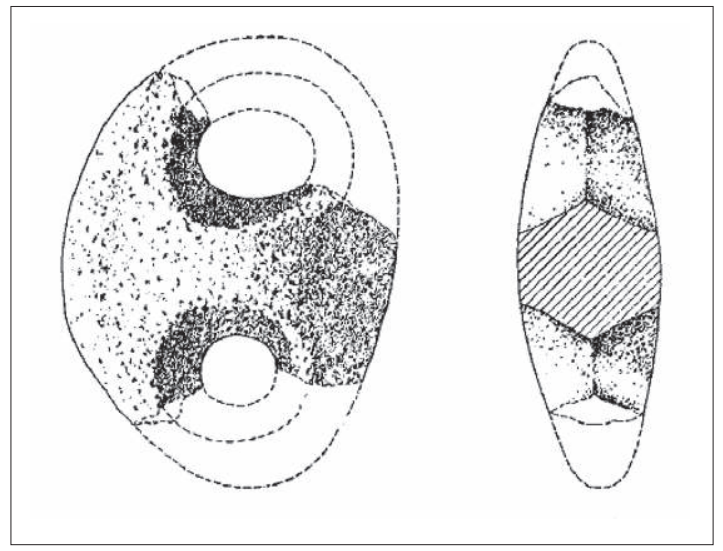

Fig. 5 - Double-perforated stone from Las Acequías (after Haury 1945). L: $9^{1 / 2}$ inches $(23 \mathrm{~cm})$

Baffled by the unusual aspect of these artefacts, these authors first offered a possible interpretation as clay-crushers (Moorehead 1906; Haury 1945), sometimes providing morphological precisions, such as stirrup-pounders or stirrup-crushers. A few pieces are badly worn, which may be an evidence of their use as crushers, but can also be the result of natural erosion. None of these artefacts has ever been properly studied or subjected to microscopic analysis. Only a close microscopic examination and/or physical and chemical analysis might disclose remains of their use to crush other materials or of traces of ropes.

We must mention the presence of engravings upon items 1 and 5, an unusual feature for grinding stones. Cushing (quoted by Haury 1945, note 280) provided a half-hearted interpretation of handstones as door weights. As mentioned above, 37 years ago, Wilcox and Sternberg (1983), inspired by Borhegyi's study of morphologically similar Mesoamerican artefacts (1961), offered a cautious interpretation as ballgame-related artefacts, but without developing 
further their hypothesis. In the meantime, our knowledge and understanding of Mesoamerican manoplas has somewhat expanded (Taladoire 2016), thus allowing for a renewed interpretation of the Hohokam handstones.

\section{Borhegyi's studies of handstones}

It is, then, worth dealing with Borhegyi's theory $(1961,1964,1967,1980)$ and its antecedents in Mesoamerica. In 1957, the famous collector and artist Miguel Covarrubias (1957, p. 174, fig. 72) dedicated a few lines and four illustrations to a peculiar set of objects of unknown function, which he cautiously related to the ballgame, along with the famous set of artefacts generally known as the yugo/hacha/palma (yokes, thin stone heads, palms) complex. He identified four morphological categories: manoplas (handstones), candados (padlocks), rieles (rails) and piedras con punta lateral (lateral point or spiked handstones) (Figure 6).

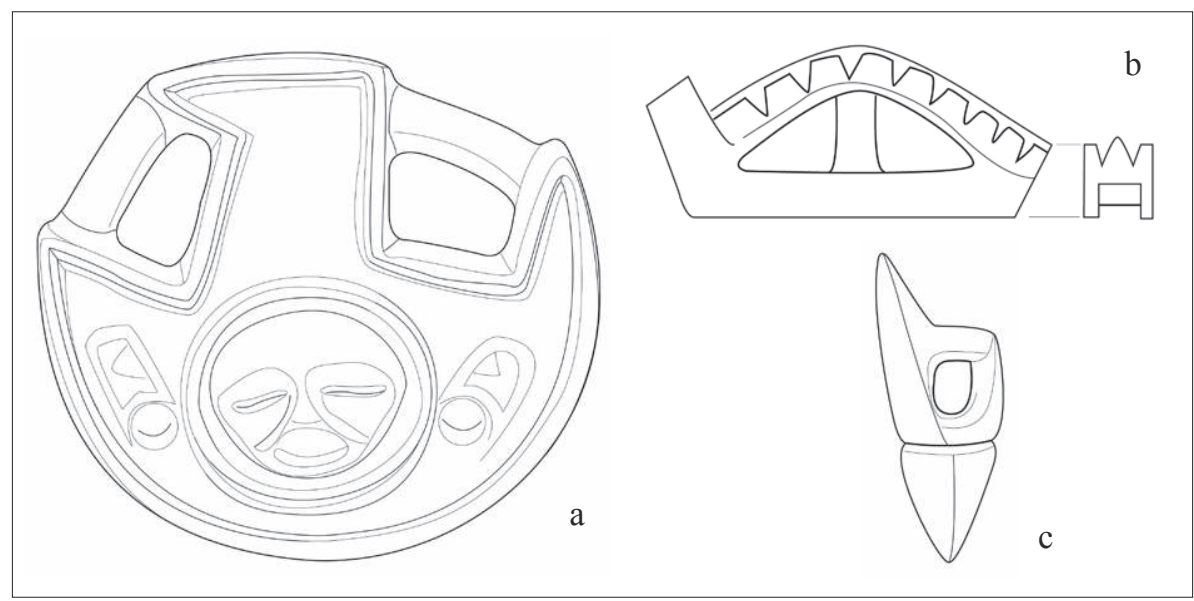

Fig. 6 - Padlock (a), rail (b) and spiked handstones (c), after Covarrubias 1957 (drawing by S. Éliès)

Borhegyi $(1961,1967)$ focused his attention on handstones and registered a total of 24 examples, mostly from the Guatemala Highlands (17), but also Tabasco (La Venta, one) and Veracruz (the Dehesa collection, five, Weiant's discoveries at Tres Zapotes). ${ }^{1}$ Curiously echoing Fewkes and while he was aware of the latter's interest in the Dehesa collection, Borhegyi ignored the

1. In his latest publications on the topic, he documented a few more pieces. But the Tres Zapotes items found by Weiant might rather be considered as polishing artefacts (Taladoire 2016). 
Hohokam artefacts. In agreement with Borhegyi's contribution, we may provide a preliminary basic definition. A handstone is a spherical/ovoid or bottle-shaped portative artefact (Figure 7a, b), generally made of hard stones (basalt, lava, porphyry), ${ }^{2}$ with a top perforated handle, wide enough to allow the hand to grab the handle (Taladoire 2016, fig. 4). In most cases, they have a round base, which means that they were not intended to stand on the ground, thus being portative items. Only the spherical or ovoid sub-type is documented in Arizona (Figures 2, 3, 4). Curiously, the double-perforated stone ( $\mathrm{n}^{\circ} 15$; Haury 1945, p. 169, fig. 107, plate 81h) from Las Acequías (Figure 5) resembles Covarrubias's padlocks (Figure 6a). ${ }^{3}$

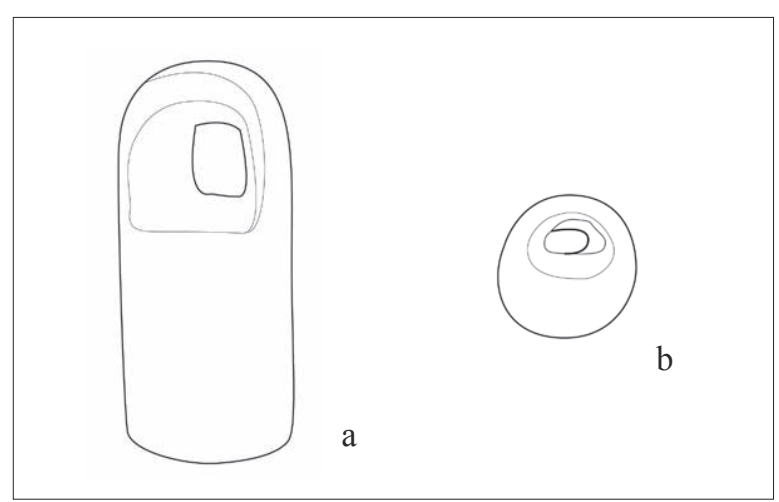

Fig. 7 - Basic handstone morphology (drawings by S. Éliès):

a. Bottle-shape handstone (Table 2, $\mathrm{n}^{\circ} 58$ ); b. Spherical handstone (Table 2, $\mathrm{n}^{\circ} 47$ )

Borhegyi then proceeded to a critical examination and rejection of previous interpretations of these artefacts as arms or slingstones (Fewkes 1907; Follett 1932), or grinding implements (clay-crushers, machacadoras). He based his argument upon the relatively good preservation of most items. The same arguments stand for most Hohokam crushers. In his criticism of Borhegyi's work, Clune (1963) forwarded another hypothesis as hand irons, an explanation that Borhegyi does not reject entirely. Borhegyi then noted the similarity of their global geographical repartition with the yugo/hacha/palma complex. Since these last artefacts were (and still frequently are) considered as ballplayers'

2. The Tikal pieces were made of probably local limestone. It is worth mentioning also that in a few instances, precious stones like alabaster (Table $\left.2, \mathrm{n}^{\circ} 68\right)$, tecalli $\left(\mathrm{n}^{\circ} 25\right)$, or green $\left(n^{\circ} 06,49,66,67,78\right)$ stone were preferred, an indication of their ritual value.

3. Curiously, Las Acequías is precisely one of the Hohokam sites where no ballcourt has been identified. 
paraphernalia (Kurosaki Maekawa 2006; Roose 2006), Borhegyi offered an explanation of handstones as ballgame-related items.

In the absence of detailed data and macroscopic analysis, he then proceeded to document his interpretation through a thorough inventory of available iconographic evidence, taking into account the main ballcourt (2D1) panels of Chichen Itza, the Lubaantun figurines (Joyce 1933) and numerous other occurrences (sculptures, figurines, codices). Since he aimed to assert a link between handstones and the ballgame, he preferred not to leave out any kind of hand-protective artefacts, including gloves, bandaged hands, arm wrappings and other protective items (Borhegyi 1961, Chart 1). But he cautiously differentiated handstones from gloves or mitts that he only used for comparative purpose. Handstones, as portative objects with a handle, differ completely from the gloves and arm wrappings that numerous players (even nowadays) wear in order to protect their hands when they hurl themselves to the ground to catch a ball, as illustrated in the Weiditz engraving (Figure 8), in codices or on carved monuments (Figure 9).

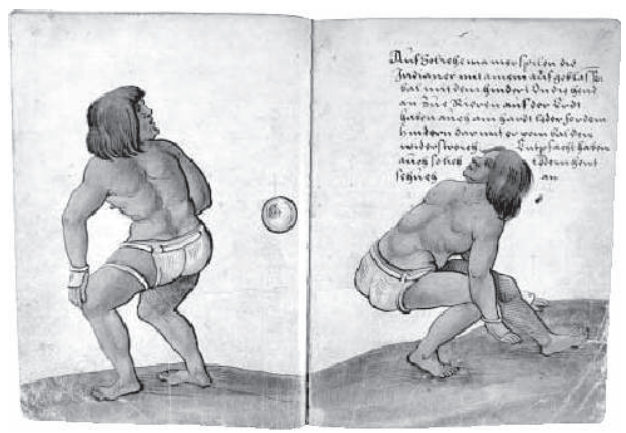

Fig. 8 - Weiditz engraving, where the hand protections can clearly be seen (after

Weiditz Christoph, Das Trachtenbuch des Christoph Weiditz von seinen Reisen nach Spanien (1529) und die Niderlanden (1531-1532), Berlin und Leipzig, 1927)

Unfortunately, in spite of his detailed and prudent approach, many subsequent authors added to his list a large quantity of eclectic, unidentified objects, such as the Olmec knuckle-dusters. This resulted in a morphological and functional confusion that needed a thorough revision before a homogeneous corpus could be defined.

Through a systematic analysis (Taladoire 2016), we have been able to exclude several categories of unrelated artefacts, i.e. the Olmec knuckle-dusters, also discarded by Taube (2004), ${ }^{4}$ and to differentiate between rails (two examples),

4. Borhegyi also refuted such assimilation between handstones and the knuckle-dusters. 


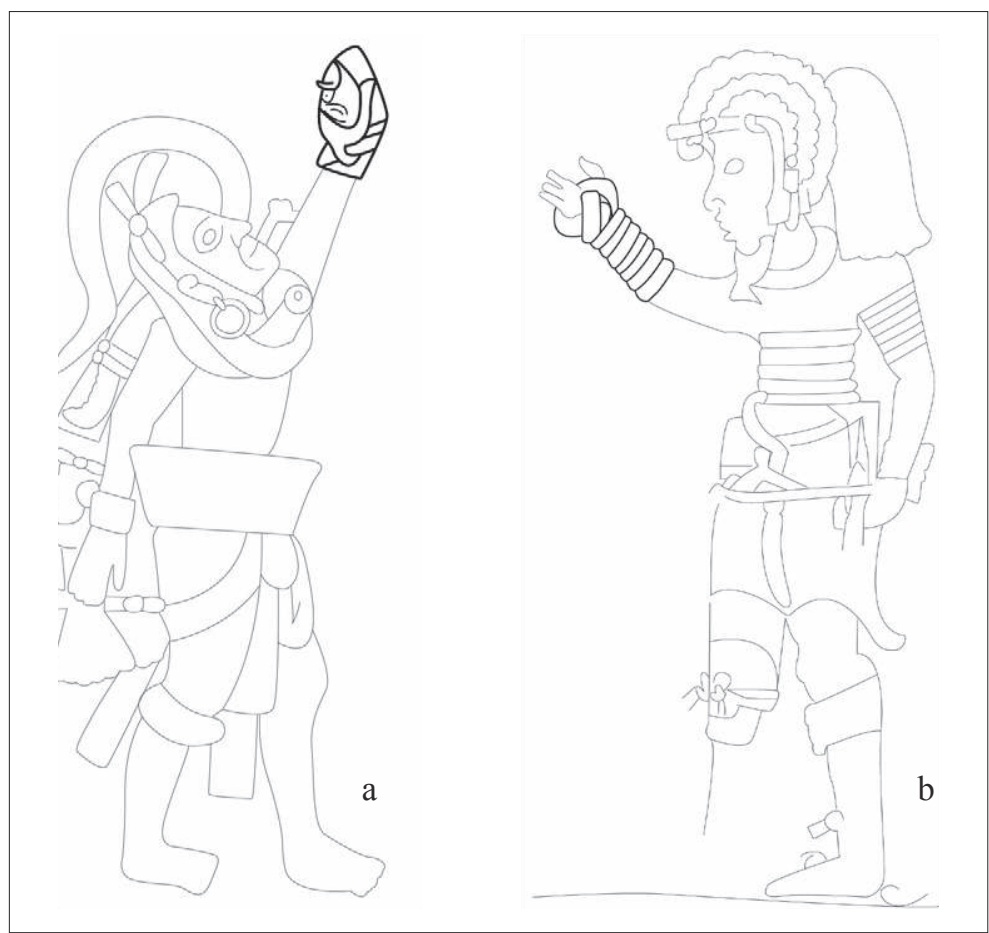

Fig. 9 - Gloves and protective wrappings used by ballplayers (drawing by S. Éliès):

a. Cotzumalhuapa stela $n^{\circ} 3$; b. The Tepatlaxco stela

spiked handstones ( 5 examples), padlocks (16 or 17 examples) (see Figure 6a) and what might properly be called handstones, in conformity with Borhegyi's and our definition.

Taube (2017), and Taube and Zender (2009, p. 194, fig. 7-19) included in their study of boxing and related paraphernalia two perforated stone spheres from Chiapa de Corzo (Lee 1969), the Piedras Negras "handstone" (probably a stone ball) and two objects from the Museum of Cozumel and the American Museum of Natural History (Taladoire 2016, $n^{\circ}$ 107-111). But they remark that the pierced protuberance on these spheres is too small to accommodate anything other than a rope. Their designation as handstone is accordingly discarded.

The total of well-identified Mesoamerican handstones amounts to 80 pieces, only 16 of them from controlled excavations, albeit not in stratigraphic context, save for the Oztoyahualco and Caracol examples (Table $2, n^{\circ} 76,77$ ). This is only an evaluation, since some pieces might have escaped our attention. On the other hand, a few non-described handstones from private collections in Guatemala (Thompson 1943; Table 2, $n^{\circ} 44,45,46$ ) might have been later sold in auctions 
and registered twice. Lastly, we must not discard possible falsifications. Since the publication of my article (2016), one more object, described erroneously as a handstone from Guerrero, has surfaced in a private gallery in Paris. It corresponds to the padlock category. ${ }^{5}$

Table 2 - Documented handstones from Mesoamerica

(MAX: Museum of Anthropology at Xalapa)

\begin{tabular}{|c|c|}
\hline 01 & $\begin{array}{l}\text { AX? Dehesa Coll. (Fewkes 1907, fig. 60). Xico-Cempoala. Undated. Ovoid, with a } \\
\text { p handle, large perforation. }\end{array}$ \\
\hline 02 & $\begin{array}{l}\text { AX? Dehesa Coll. (Fewkes 1907, fig. 60). Xico-Cempoala. Undated. Globular, large } \\
\text { rcular handle, underlined by a deep groove. Large perforation. }\end{array}$ \\
\hline 03 & $\begin{array}{l}\text { AX? Dehesa Coll. (Fewkes 1907, fig. 61). Xico-Cempoala. Undated. Globular with a } \\
\text { ge circular handle, underlined by a deep groove. Large perforation. }\end{array}$ \\
\hline 04 & $\begin{array}{l}\text { ed. Conical, eroded } \\
\text { foration. }\end{array}$ \\
\hline 05 & $\begin{array}{l}\text { AX? Dehesa Coll. (Fewkes 1907, fig. 61). Xico-Cempoala. Undated. Globular, small } \\
\text { perior handle. Protuberances on the belly. }\end{array}$ \\
\hline 06 & $\begin{array}{l}\text { AX } 00232 \text { (Scott 1978, fig. 14). (https://sapp.uv.mx/catalogomax/es-MX/sala/ } \\
\text { talles/834). Papaloapan Basin, Veracruz, according to Scott. Classic. L: } 32.5 \text {, W: } 9.5 \text {, } \\
\text { 13.5. Green stone. Elongated square morphology, with rounded angles. Handle on the } \\
\text { per part. The lower part represents a jaguar's head, with human hands on both sides. } \\
\text { cised motifs on one face (glyphs?). }\end{array}$ \\
\hline 07 & $\begin{array}{l}\text { 639). Unknown } \\
\text { lle. Tripod base. }\end{array}$ \\
\hline 08 & $\begin{array}{l}\text { l Carrizal (Ver.). } \\
\text { es on the belly. }\end{array}$ \\
\hline 09 & $\begin{array}{l}1 \text { Carrizal (Ver). } \\
\text { ves on the belly. }\end{array}$ \\
\hline 10 & $\begin{array}{l}\text { AX } 09120 \text { (https://sapp.uv.mx/catalogomax/es-MX/sala/detalles/667). Central } \\
\text { eracruz. Postclassic. H: } 12.3 \text {, D: } 8 \text {. Globular base, with vertical grooves on the body. } \\
\text { ide handle, separated from the belly by a deep groove. }\end{array}$ \\
\hline 11 & a/detalles/753). Unknown \\
\hline 12 & $\begin{array}{l}\text { AX } 00381 \text { (Scott 1978, fig. 13; Cuevas 1970). El Carrizal, Veracruz, Str. 38, sep. } 2 . \\
\text { assic. H: 16, L: 6. Long cylindrical form with a narrow handle. Limestone. A yoke } \\
\text { und alongside. }\end{array}$ \\
\hline 13 & (Scott 1978, fig. 13; Cuevas 1970). El Carrizal, Veracruz, Str. 54, \\
\hline 14 & $\begin{array}{l}\text { MAX 061700L-2(1). Veracruz. Undated. H: 14.1. Globular with a flat base. Wide round } \\
\text { handle. }\end{array}$ \\
\hline & \\
\hline
\end{tabular}

5. Paris, private gallery. Paddlock, Guerrero, Mexico, AD 300-900. Rounded object with two perforations, and two handles. Three teeth on one side. Green grauwacke with darker through vein. $\mathrm{H} 29 \times \mathrm{W} 43.4 \times \mathrm{D} 6.8 \mathrm{~cm}$. 
16 MAX A5558. Veracruz. L: 9.8, W: 10, H: 15.5. Undated. Semi-globular. Wide round handle.

17 MAX 00768. Veracruz. Classic. H: 13, W: 10, L: 9. Ovoid. Wide round handle.

18 MAX 00511. Veracruz. L: 10.9, W: 11.2, H: 17.1. Undated. Ovoid. Wide oval handle.

19 MAX 09315. Piedras Negras, Veracruz. Classic. 6.6 x 8.4. Globular, with perforation.

20 MAX 00767. Veracruz. Classic. L: 9.5, W: 11.5, H: 5. Elongated form, incomplete perforation.

21 MNA 4-1502 (El juego de pelota 1986, fig. 25). Veracruz. Classic. H: 10.5, D: 10. Spherical, with a central perforation. Intertwined protuberances.

22 MNA 4-1019 (El juego de pelota 1986, fig. 26; El juego de pelota 1992, n 27). Veracruz. Late Classic. H: 11.4, D: 11.1. Spherical, representing a jaguar's head. Oval top handle.

MNA 6-77 (El juego de pelota 1986, fig. 73; El juego de pelota 1992, n 14; Seler 1991).

23 Monte Alban. Classic. D: 10.4. Spherical, representing a jaguar's or a bat's head. Tears on the cheeks.

MNA 10-228684 (El juego de pelota 1986, fig. 73; El juego de pelota 1992, no 14).

24 Mixteca, Acatlán de Pérez. Postclassic. H: 19.5, L: 24. Sub-circular, flat, with a central handle underlined by a groove. Rectangular motifs on the handle.

25 MNA (Piña Chan 1968, fig. 21). Southern Veracruz. Classic. H: 12, D: 11. Sphere with a superior non-perforated depression. Tecalli.

26 MNA 6-7842 (El juego de pelota 1992, fig. 13). Oaxaca. Classic. D: 10.3, H: 13.2. 6 Bottle-shaped with rounded base. Oval handle. Reticular incisions. Worn, eroded.

27 MNA 6-7978 (El juego de pelota 1992, fig. 15). Oaxaca. Classic. D: 12.5. Spherical, oval handle. Wide perforation.

28 Museo Nacional Guatemala 4426 (Borhegyi 1961, fig. 7-3). Los Cerritos. H: 23, D: 16.5.

28 Undated. Oval shape, rounded base separated from the oval handle by a fine groove.

29 Museo Nacional Guatemala 2816 (Borhegyi 1961, fig. 7-4). Kaminaljuyú. H: 20, L: 13. Undated. Flat sub-triangular, with an oval central perforation.

Museo Nacional Guatemala or Hannstein coll. (Borhegyi 1961, fig. 7-5). Patzun

30 (Guatemala). H: 22, L: 13. Undated. Flat discoid with a wide superior handle. Incised face on the belly.

31 Museo Nacional Guatemala 2146(Borhegyi 1961, fig. 7-6). Unknown prov. H: 22.5, L: 15.5.

31 Undated. Flat rectangular, with a narrow handle. Crying human face (Quetzalcoatl?).

32 Museo Nacional Guatemala 2189 (Borhegyi 1961, fig. 7-7). Unknown prov. H: 19.3, L: 15.5.

32 Undated. Flat rectangular, narrow superior perforation. Plain human face on the belly.

33 Museo Nacional Guatemala 2147 (Borhegyi 1961, fig. 7-8). Unknown prov. H: 23.5, L: 14.

33 Undated. Rectangular, upper narrow round handle. Human face in tears (Quetzalcoatl?).

34 Museo Nacional Guatemala 7541b (Borhegyi 1961, fig. 7-2). Unknown prov. L: 15.5, W: $15.2 .4 \mathrm{~kg}$. Undated. Globular, with a non-perforated superior handle.

35 Museo Nacional Guatemala 7541 (Borhegyi 1961, fig. 8-1). Unknown prov. H: 13, D: 12. Undated. Rounded jaguar's head in low relief. Large posterior oval handle.

36 Museo Nacional Guatemala 1902 (Borhegyi 1961). Undated. Plain sphere with top handle.

37 Leff Coll. Pittsburgh (Borhegyi 1961, fig. 8-2/3). Unknown prov. (Veracruz?) H: 14, D: 14. Undated. Incised spherical jaguar's head. Wide oval handle.

38 El Baúl (Thompson 1948, p. 24, fig. 18; Borhegyi 1961, fig. 7-1). H: 27, D: 23. Undated. Polished sphere with a wide superior handle.

40 Chichicastenango Museum 765a, and b (Borhegyi 1961; Lothrop 1936, p. 60, fig. 65). Zacualpa. Location unknown. Undated. Two fragments. No description.

41 Tajumulco (Dutton and Hobbs 1943, p. 51-52; Borhegyi 1961). 6.4 x 3.3. Location unknown. Early Postclassic. Plain fragment. Traces of red paint (hematite). 
42 Tajumulco (Dutton and Hobbs 1943, p. 51-52; Borhegyi 1961). 7.2 x 12.8. Location unknown. Early Postclassic. Fragment of a well-polished handstone, with handle. Hard stone.

43 Tajumulco (Dutton and Hobbs 1943, p. 51-52; Borhegyi 1961). 4.2 x 3.4. Location unknown. Early Postclassic. Fragment. Porphyry.

44 Montes Coll. Finca Buenos Aires (Thompson 1943, p. 107; Borhegyi 1961). No description.

45 Robles Coll. Finca El Paraíso (Thompson 1943, p. 107; 1948, p. 24, fig. 18j; Borhegyi 1961). No description.

46 Robles Coll. Finca Tinhuinlinhuitz (Thompson 1943, p. 107; Borhegyi 1961). No description.

47 Herrera Coll. El Baúl (Thompson 1948, p. 24, fig. 18h, I; Borhegyi 1961). Undated. Jaguar's paw morphology. Small sub-rectangular. Square handle.

48 La Venta (Museum) (Borhegyi 1967, fig. 2a). Middle Preclassic. H: 24, D: 15. Elongated sphere with a narrow handle.

49 Xico, Site Museum. Unknown prov. Undated. Plain elliptic form with a thick handle and narrow perforation. Green stone.

Santiago Tuxtla Museum. (http://www.latinamericanstudies.org/santiago-tuxtla/san-

50 tiago-tuxtla-21.jpg, center). Unknown prov. Undated. Flattened sphere, with a wide circular handle tied to the belly and underlined by a fine groove.

Santiago Tuxtla Museum. (http://www.latinamericanstudies.org/santiago-tuxtla/san-

51 tiago-tuxtla-21.jpg, right). Unknown prov. Undated. Flattened sphere with a wide circular handle.

Milwaukee Public Museum 54146/20006 (Borhegyi 1967, fig. 1; Leyenaar and

52 Parsons 1988, fig. 48). Veracruz. Preclassic or Late Classic? H: 10, D: 10. 845 gr. Sphere with a wide handle. Protuberances on the belly.

Milwaukee Public Museum (Leyenaar-Parsons 1988, p. 48). Veracruz. Classic. H: 11.5.

53 Basalt. Sphere, oval handle underlined by a groove and a central depression. Intertwined protuberances.

54 Milwaukee Public Museum 55230/20696 (Borghegyi 1980, fig. 20a). Kaminaljuyú. Preclassic. H: 12, L: 15. Manopla without perforation, or handle. Two lateral cavities. Basalt.

55 Chicago Natural History Museum (Borhegyi 1961; Thompson 1941, fig. 33 f; Ekholm 1946, pl. 3g, h.). Unknown prov. Undated. Human head form. Perforation.

56 Leiden Rijksmuseum Museum voor Volkenkunde, RMV 5493-1 (Leyenaar 1997, 6 fig. 57). Tabasco. Late Preclassic. H: 19.6. Cylinder with a narrow superior handle.

57 Leiden Rijksmuseum voor Volkenkunde (Leyenaar and Parsons 1988, p. 50). Veracruz. 7 Undated. H: 14. Bottle-shaped with rounded base and oval handle. Crossed incisions.

58 Leiden Rijksmuseum voor Volkenkunde (Leyenaar and Parsons 1988, p. 43). Tabasco. Preclassic. H: 15.3. Worn cylinder with an oval handle.

59 Staatliches Museum für Völkerkunde, Munich (Leyenaar and Parsons 1988, p. 45). Guatemala. D: 12.9. Undated. Narrow with an oval handle.

60 Staatliches Museum für Völkerkunde, Munich (Leyenaar and Parsons 1988, p. 46). Quetzaltenango. Early Classic. H: 14. Sphere with an oval handle.

Staatliches Museum für Völkerkunde, Munich (Leyenaar and Parsons 1988, p. 47).

61 Chilantlatla. 35 x 21.5. Undated. Flat rectangular, with a round superior handle. Stucco, traces of red paint.

62 Museum für Völkerkunde, Berlin (Leyenaar and Parsons 1988, p. 49). Veracruz or Guatemala. D: 13.5. Undated. Sphere with an oval handle. Incised motifs. Volcanic stone. Sphere with a handle. Jaguar's face incised. 
Museum Primitive Art 63.58 (Borghegyi 1980, fig. 13a). Veracruz. Protoclassic. H: 17.5.

64 Hemispheric with an oval handle. Anthropomorphic face with closed eyes and tears on the cheeks.

65 Snite Museum (https://commons.wikimedia.org/wiki/File:Manopla_\%26 ballplayer

65 figurine_(Snite).jpg, Snite 1994.015). Veracruz. Classic. D: 10.49. Spherical with a wide handle. Basalt.

Snite Museum (http://commons.wikimedia.org/wiki/File:Mesoamerica_-_manopla

66 and_ball.jpg). Kaminaljuyú. 900 BC-AD 250. No perforation, lateral cavity. Eroded. Rubber traces.

Ethnologisches Museum Berlin (https://www.deutsche-digitale-bibliothek.de/searchre-

67 sults? query=IV+Ca+47084+) Veracruz. Preclassic. 11,2 x 13,3 x 9.9. Spherical. The handle is not visible. A hand is incised on the body. Green stone.

Los Angeles County Museum AC1996.146.52. Teotihuacán. 10.16 x 11.43. Undated.

68 Hemispheric with a narrow almost rectangular handle. Protuberances on the belly. Green alabaster. (https://commons.wikimedia.org/wiki/File:Handstone_LACMA_ AC1996.146.52.jpg).

Mint Museum (Whittington 2001, p. 97). Veracruz (Kaminaljuyú according the Snite

69 Museum). Late Classic. H: 17.8. Zoomorphic, representing a monkey. Wide ellipsoidal handle. Traces of red paint.

Princeton Art Museum, J. B. Elliott Coll. (Miller 1989, fig. 16. 1990-17, https://artmu-

70 seum.princeton.edu/collections/objects/3338). Veracruz, Early Classic or Oaxaca, Late Classic. D: 14.9. Spherical with handle, representing a jaguar's face with fangs.

71 Tikal (Moholy-Nagy 2011, fig. B: 107d). Classic. D: 13.6. Location unknown. Spherical with handle. Limestone.

72 Tikal (Moholy-Nagy 2011, fig. B: 107d). Classic. Location unknown. Handle fragment. Limestone.

73 Tikal (Moholy-Nagy 2011, fig. B: 107d). Classic. Location unknown. Handle fragment. Limestone.

74 Tikal (Moholy-Nagy 2011, fig. B: 107d). Classic. Location unknown. Handle fragment.

74 Limestone.

75 Tikal (Moholy-Nagy 2011, fig. B: 107d). Classic. Location unknown. Handle fragment. Limestone.

Caracol (Belize), sep. (Taube and Zender 2009, fig. 7-15). Early Classic. Location

76 unknown. $2.4 \mathrm{~kg}$. Skull form. The lower jaw forms the handle, with a large perforation. Limestone.

Oztoyahualco, Cuarto 10, sep. 13 (Manzanilla 1993, fig. 389; Taube and Zender 2009,

77 fig. 7-15). Teotihuacan, Early Classic. Location unknown (Teotihuacan bodegas?). W: 9,

77 H: 9.6. Soft sandstone. In form of a skull, the perforation represents the mouth. Sub rectangular handle.

78 Kislak Coll. (Dunkelman 2007, fig. 121). Oaxaca. Late Preclassic. H: 19, D: 15.3. 8 Hemispheric anthropomorphic. The handle is not shown. Green stone. Cocijo face.

Barakat Coll. MT 0292 (http://www.antiques.com/classified/1097636/Antique-Mayan-

79 Basalt-Manopla). Maya. Classic. D: 13.3 H: 10.2. Basalt. Globular con large semi-circular handle. Incised scrolls on the belly.

80 Auction Sotheby's 2006 (Lot 338). Maya? Globular, with an ellipsoidal perforation. Two superior perforations represent the eyes. Anthropomorphic. Limestone. 
The Mesoamerican corpus may be divided into several subcategories. Plain handstones, whether spherical, discoid or bottle-shaped, number 40 items, mainly from Veracruz and Guatemala. The five Tikal handstone fragments belong to this group. Sometimes, a thin groove separates the main body from the handle. Sixteen handstones are decorated with simple geometric motifs, such as incisions, grooves or small conical protuberances. Twenty others can be described as anthropozoomorphic. Some have a flat rectangular form, with a handle at one extremity. Most often, the main motif is a human $\left(\mathrm{n}^{\circ} 30,32,55,80\right)$ or animal face (jaguar $\mathrm{n}^{\circ} 22,23,35,37,63,70$; monkey, $\mathrm{n}^{\circ} 69$ ). A few examples depict a human face in tears that is audaciously interpreted by Borhegyi as a representation of deities, Quetzalcóatl ( $n^{\circ} 31,33$, maybe 64) or Cocijo (78). Handstone $\mathrm{n}^{\circ} 6$ represents the upper part of the body of an anthropomorphic jaguar, with human hands on both sides. It reminds the very elaborated representation of item 47, in the form of a jaguar paw. Finally, the Caracol and Oztoyahualco handstones ( $\mathrm{n}^{\circ} 76$ and 77 ), both from funerary contexts, represent skulls, the perforated opening figuring the mouth and the lower jaw serving as the handle. Both are exceptional representations.

It is useful to insist upon such differences since, while most Hohokam handstones fall perfectly in the first plain category, two items ( ${ }^{\circ} 1: 61 / 599$ ASU, and $n^{\circ}$ 5: 68/250 ASU, Figure 3 upper and lower left) bear what seem to be incised, geometrical motifs, thus presenting some similarity with our second subcategory.

\section{Size and weight}

It is worth dwelling upon the technical aspects of dimensions and weight. Unfortunately, we have very few data on the weight, with only three known examples from Mesoamerica: $\mathrm{n}^{\circ} 34$ and $76(2.4 \mathrm{~kg}), \mathrm{n}^{\circ} 52(0.845 \mathrm{~kg})$. The data on the Hohokam specimens are more numerous, with 8 examples: $n^{\circ} 2$ (67/432 ASU) weighs only $0.58 \mathrm{~kg}, \mathrm{n}^{\circ} 5(68 / 250 \mathrm{ASU})$ and 7 (Los Muertos) are the heaviest with $4.54 \mathrm{~kg}$. All other documented examples ( $\mathrm{n}^{\circ}$ 1, 3, 4, 6 and 8) fall in between $1.8 \mathrm{~kg}$ and $2.9 \mathrm{~kg}$, more or less the same weight as the documented Mesoamerican examples.

While they are not always systematic, we have more data upon the dimensions (Tables 1 and 2). Due to the morphological diversity and the different methods used by the authors, measurements can only be indicative. The diameters of globular items vary from 7.4 to $16.5 \mathrm{~cm}$, with one item reaching up to $23 \mathrm{~cm}$. As for total heights, they vary from 8.4 to $35 \mathrm{~cm}$, with a majority of objects, whatever their origin, between 10.3 and $27 \mathrm{~cm}$. Only one Hohokam item ( ${ }^{\circ} 14$ : 254496; Fewkes 1912, p. 129, plate 66b) reaches $60 \mathrm{~cm}$, which means that it might not fit within the handstone category. Save for this example and $\mathrm{n}^{\mathrm{o}} 15$, already mentioned, we may consider that the Hohokam handstones present 
a surprising similarity with the Mesoamerican corpus and correspond to our definition as portative artefacts. Last but not least, the perforation dimensions, when available, easily allow the hand to grab the handle.

\section{Chronological and geographical repartition}

Since most handstones do not proceed from controlled excavations, their dating remains approximate. We can only rely on 16 items in archaeological context, but even so, most were discovered among surface remains (La Venta, Tajumulco, El Carrizal). Most chronological placements are thus very tentative, based rather on a comparative approach. From the available data, these objects date from the beginning of the Late Preclassic (maybe a bit earlier at La Venta) to the Early Postclassic (El Carrizal, Tajumulco). The apogee would occur between the Early Classic (300-600, Teotihuacan, Kaminaljuyú) and the Late Classic (600-850, Tikal). While very approximate, this chronological placement partly overlaps the proposed dating of the Hohokam handstones, from the Colonial (800-950) or Sedentary (950-1150) periods, all the more if our hypothesis of an importation is correct, with the necessary delay of transmission.

The geographical repartition is also quite imprecise, while slightly better documented. The handstones have mostly been found in central and southern Veracruz, adjoining areas of Tabasco, Oaxaca and Chiapas and on the Pacific coast of Guatemala. This repartition corresponds to what Parsons (1978) calls the Peripheral Coastal Lowlands, the region from which come most known examples of the yugo/hacha/palma complex. Only 8 items proceed from the Maya Lowlands (Tikal and Caracol, plus two doubtful items from galleries, $\mathrm{n}^{\circ} 79$ and 80) and one from Oztoyahualco (Teotihuacan, Manzanilla 1993; Taube and Zender 2009). According to Linda Manzanilla, the Oztoyahualco handstone was probably imported from the Gulf coast. It seems to be the westernmost occurrence. Another unidentified piece from Colima is worth mentioning. In his catalogue of sculptures from western Mexico, Williams (1992, fig. 174) illustrates a zoomorphic sculpture from Armería (Colima) that looks like the horizontal handstones worn by the Chichen Itza ballplayers. Since we lack any more details such as the discovery context, dimensions or chronological placement, it is impossible to go further in its interpretation.

This geographical repartition is quite coherent in the Mesoamerican context: handstones have been found only in eastern Mesoamerica and, apart from the possible Colima sculpture, they are totally absent in northern and western Mesoamerica. Obviously, the number of well-excavated ballcourt sites is also much more reduced, leaving open the possibility of new discoveries. Contrary to the chronological placement, anyway, this repartition is presently quite puzzling since it raises more questions about the supposed Hohokam items and their origin. 


\section{Functional analysis}

Our comparative study of both corpuses allowed us to establish their relative morphological similarity and their compatibility. Even if the Hohokam item $\mathrm{n}^{\circ} 15$ (Haury 1945, p. 169, fig. 107) can be excluded from the corpus, its resemblance to the padlock stones paradoxically reinforces our hypothesis of these Hohokam artefacts as possible examples of Mesoamerican relationships. While, then, handstones are defined as spherical/ovoid or bottle-shaped portative artefacts, is it possible to follow Borhegyi's interpretation of these objects as ballgame paraphernalia? May we consider them as grinding or multi-functional tools? Or both?

The former interpretations of handstones as arms (slingstones), door weights or clay-crushers have already been discussed and discarded, even if Borhegyi does not exclude the use of some items, such as one of the Tajumulco examples $\left(n^{\circ} 41\right)$, to crush pigments, red hematite in this case. But these traces could also be interpreted as the remnants of decorative paintings. Traces of latex have also been identified on item 66 from Kaminaljuyú (Table 2), thus suggesting a possible crushing function or activity. But rubber is also precisely the material from which balls were made: its presence might result from its use related with the game. Anyway, two out of 80 Mesoamerican items are not significant, but since most examples have not been properly analysed, we cannot discard this hypothesis completely.

According to Wilcox and Sternberg (1983), most Hohokam items do not show "any sign of battering and pounding," apart from Fewkes's worn-out artefacts. A few other Mesoamerican items ( $\mathrm{n}^{\circ}$ 26, for instance) can be mentioned. But, in these cases, the wear looks more like a consequence of natural erosion than of grinding activities. We must also keep in mind the presence of decorative motifs at least in two of the Hohokam items and in 23 Mesoamerican examples out of 80 . For what purpose would grinding tools be engraved (or painted in the Tajumulco example)?

Basing his functional interpretation upon their geo-chronological repartition, Borhegyi first remarked on the "frequent" association of handstones with yokes and palmate stones. As a matter of fact, if the repartition areas are more or less similar, the only case of direct association of a handstone with a yoke comes from El Carrizal (Table 2, $\mathrm{n}^{\circ} 12$ ), a discovery that occurred later (Cuevas 1970). After developing his comparative approach, Borhegyi (1961, p. 138) suggested that handstones "were probably used to deflect the ball, protect the hand and steady the player in the pre-Columbian ball game." In his comments, Clune (1963) remarked that the use of handstones during the game is highly unlikely. The mere morphological diversity would prevent any practical use, and, furthermore, the existence of even low-relief motifs (Figure 10) on numerous handstones (36 Mesoamerican examples) would have probably occasioned false rebounds, an argument to which Borhegyi subscribed. 


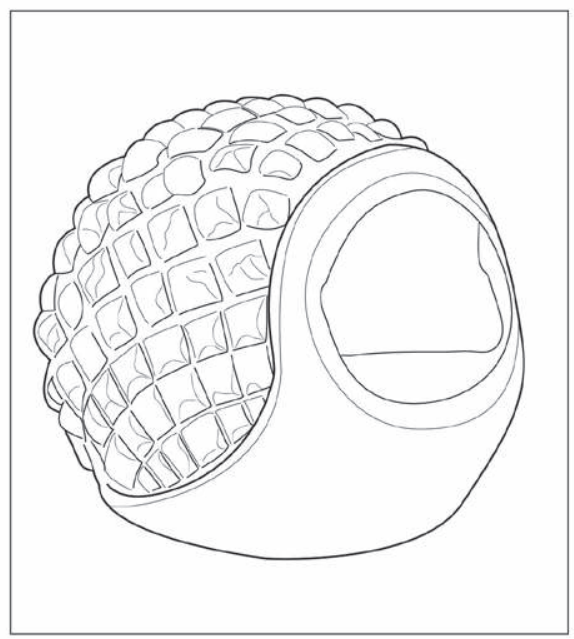

Fig. 10 - Handstone with small conical protuberances (Table 2, $\mathrm{n}^{\circ} 21$ ) (drawing by S. Éliès)

In the absence of identified functions, we can, in Borhegyi's wake, turn towards iconographical evidence. Unfortunately, we do not dispose of any known iconographical data for the Hohokam ballgame. We can only rely on the available examples from Mesoamerica.

\section{Iconographical approach}

Borhegyi developed a detailed, well-argued study. His basic premise was that handstones served "to deflect the ball or protect the players' hand." In their dense research to demonstrate the existence of "Ritual Boxing in Ancient Mesoamerica," Taube and Zender (2009) proceeded to give a thorough reexamination of available iconography. They basically rely upon the same data as Borhegyi, enriched by their own systematic research. Also discarding gloves and other protective devices, they focused upon the objects many supposed ballplayers or boxers hold in their hands, such as the spherical items depicted in the Dainzú slabs (Bernal 1968) or the Lubaantun figurines (Joyce 1933). It would be pointless here to dwell upon the nature of the game played by the individuals depicted in both sites (Taube 2017; Taube and Zender 2009; Taladoire 2003, 2016). A close examination of their lists, of Borhegyi's data and of our own research permitted discarding many representations, such as precisely the Dainzú or Lubaantun helmeted individuals, who hold small spherical objects without handles. The same is true for numerous figurines, as well as for many representations registered by Taube and Zender (2009). In conformity with our definition of handstones (a spherical/ovoid, rectangular 
or bottle-shaped portative artefact, with a top handle and a wide top perforation), we registered a reliable corpus of 16 representations documented in the existing literature ${ }^{6}$ (Table 3).

Table 3 - Documented iconographical representations of handstones

\begin{tabular}{|c|c|c|c|}
\hline Provenience & Artefact & Type & Main reference \\
\hline Aparicio & Stela (4) & $\begin{array}{l}\text { Bottle-shaped } \\
\text { handstones }\end{array}$ & Hellmuth 1996 \\
\hline El Tajín & Column 11, ind. C & $\begin{array}{c}\text { Bottle-shaped } \\
\text { handstone }\end{array}$ & Castillo Peña 1995 \\
\hline Veracruz & Figurine & $\begin{array}{l}\text { Spherical zoomorphic } \\
\text { handstone }\end{array}$ & $\begin{array}{l}\text { Whittington 2001, } \\
\text { fig. } 50\end{array}$ \\
\hline $\begin{array}{l}\text { Monte Alban } \\
\text { Tomb } 58\end{array}$ & Figurine & $\begin{array}{l}\text { Rectangular decora- } \\
\text { ted handstone }\end{array}$ & Taladoire 2016 \\
\hline Lubaantun & Figurine & $\begin{array}{l}\text { Bottle-shaped } \\
\text { handstone }\end{array}$ & $\begin{array}{c}\text { Taube and } \\
\text { Zender 2009, } \\
\text { fig. } 7.19 \mathrm{a}\end{array}$ \\
\hline Jaina & Figurine & Spherical handstone & $\begin{array}{c}\text { Taube and } \\
\text { Zender } 2009\end{array}$ \\
\hline Jaina & Figurine & Spherical handstone & $\begin{array}{c}\text { Leyenaar and } \\
\text { Parsons } 1988 \text {, cat. } \\
n^{\circ} 36\end{array}$ \\
\hline Chichen Itza & $\begin{array}{c}\text { Panel K4, } \\
\text { ballcourt 2D1 }\end{array}$ & $\begin{array}{l}\text { Globular zoomorphic } \\
\text { handstone }\end{array}$ & Tozzer 1957, fig. 526 \\
\hline Chichen Itza 2D1 & Panels (84 ind.) & $\begin{array}{l}\text { Horizontal zoomor- } \\
\text { phic handstone }\end{array}$ & Tozzer 1957 \\
\hline Pacific coast & Panel & $\begin{array}{l}\text { Rectangular decora- } \\
\text { ted handstone }\end{array}$ & Borhegyi 1961 \\
\hline Guatemala & Vase & $\begin{array}{l}\text { Rectangular decora- } \\
\text { ted handstone }\end{array}$ & $\begin{array}{l}\text { De la Garza and } \\
\text { Izquierdo } 1992\end{array}$ \\
\hline No prov. & Vase & Spherical handstone & $\begin{array}{l}\text { Taube and } \\
\text { Zender 2009, } \\
\text { fig. } 7.11 \mathrm{~b}\end{array}$ \\
\hline Coll. Van Dijk & Panel & $\begin{array}{l}\text { Rectangular decora- } \\
\text { ted handstone }\end{array}$ & $\begin{array}{l}\text { Leyenaar and } \\
\text { Parsons } 1988, \\
\text { cat. } 149\end{array}$ \\
\hline Gilcrease coll. & Whistle figurine & $\begin{array}{l}\text { Spherical zoomorphic } \\
\text { handstone }\end{array}$ & $\begin{array}{l}\text { Borhegyi 1961, } \\
\text { fig. 9-3 }\end{array}$ \\
\hline Gilcrease coll. & Palm & $\begin{array}{l}\text { Bottle-shaped } \\
\text { handstone }\end{array}$ & $\begin{array}{l}\text { Borhegyi 1961, } \\
\text { fig. 9-5 }\end{array}$ \\
\hline Covarrubias coll. & Figurine & $\begin{array}{l}\text { Bottle-shaped } \\
\text { handstone }\end{array}$ & Ekholm 1946, fig. 1c \\
\hline
\end{tabular}

6. For practical reasons, we consider the four Aparicio stelae and the 84 Chichen Itza players as individual case studies, without taking into account the number of occurrences. 
Their chrono-geographical repartition corresponds, when known, to the occurrences of documented handstones, that is Parsons's Peripheral Coastal Lowlands (1978) and the Classic period.

The only reliable evidence of direct association between handstones and ballplayers comes from the Chichen Itza ballcourt 2D1 (Tozzer 1957) and the Aparicio stelae (Hellmuth 1996). In both cases, handstones are represented not as objects "used to deflect the ball or protect the hand" (Borhegyi 1961, p. 138), but rather as part of the ballplayers' paraphernalia during the sacrificial rituals following a game, in both cases decapitation.

Two other representations stand out, one figurine from Lubaantun and the other from Monte Alban Tomb 58 (Figures 11a, b). The Monte Alban individual, who bears some kind of mask, has been found in a funerary context and is frequently interpreted as Xipe Totec, an Aztec deity associated with the

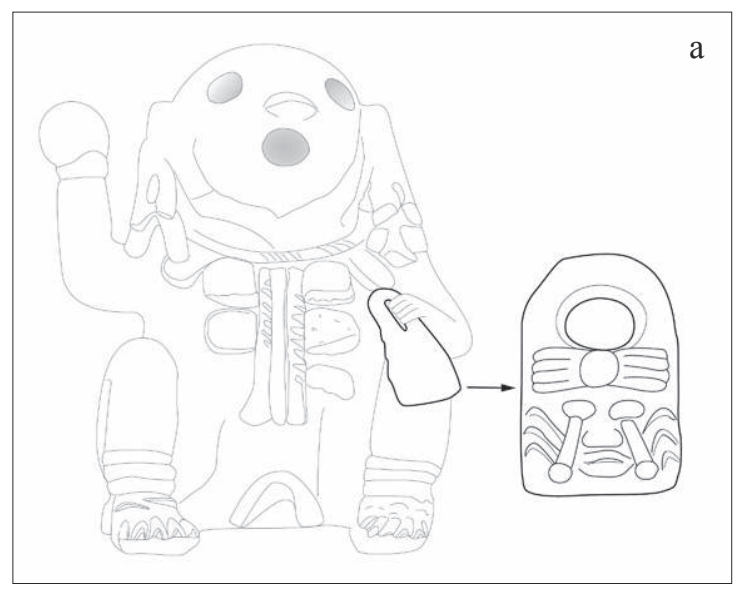

Fig. 11 - Figurines holding flat or bottle-shaped handstones (drawing by S. Éliès):

a. Monte Alban Tomb 58, figurine holding an anthropomorphic handstone; b. Lubaantun, figurine holding a handstone

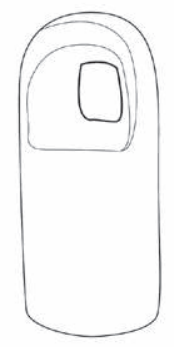


rebirth of vegetation. In both cases, a close examination reveals that, contrary to previous interpretations (Baudez 2011, 2012; Taube and Zender 2009), the objects that both individuals grasp by their handles are obviously handstones, one plain bottle-shaped (Lubaantun) and the other flat and rectangular, decorated with a human face in tears, which resembles handstones $n^{\circ} 31,33,64$ and 78.

Most other representations are currently interpreted as ballplayers through the presence of a handstone, without further analysis. The Jaina figurine (Leyenaar and Parsons 1988, cat. $\mathrm{n}^{\circ}$ 36) is a typical example of such circular reasoning: the individual holds a handstone, hence he is a ballplayer, even if he looks more like a dignitary and if nothing else relates him to any game. Taube and Zender (2009) interpret the same figurine as a boxer, on the same basis. The presence of a handstone does not mean that his holder is a ballplayer or a boxer.

To summarize, and contrary to Borhegyi's original theory, the available evidence suggests that handstones probably did not play a functional or practical role in games proper, whether boxing or the ballgame, but were rather related to post-game sacrificial rituals.

The Mesoamerican ballgame is an agricultural fertility ritual, frequently associated with decapitation, as exemplified in the Chichen Itza panels and the Aparicio stelae. Let us remember that at least two handstones (Caracol and Oztoyahualco, $\mathrm{n}^{\circ} 76$ and 77) represent skulls, thus evoking decapitation.

Taube and Zender (2009) demonstrated that boxing is also directly linked with agricultural fertility, bloodletting and rain. They emphasized the numerous occurrences in handstones and other related artefacts of representations of human faces in tears (handstones $n^{\circ} 31,33,64,78$ ). They suggested that tears and wounds symbolize rain. The Xipe Totec from Monte Alban Tomb 58, a deity clearly associated with bloody sacrificial rituals and vegetation renewal, also holds a handstone with the same motif of a human face in tears. According to the same authors and Orr (2003), jaguars are also associated with boxing and fertility rituals. They are represented on numerous handstones (at Chichen Itza and on handstones $\left.\mathrm{n}^{\circ} 6,22,23,35,37,47,63,70\right)$.

It is yet impossible to define the potential function or value of handstones in any post-game Mesoamerican ritual, to strike the victim, to crush his head or any other use. But, from the available iconographical evidence, we may assert that they were directly related with post-game sacrificial rituals of agricultural fertility.

\section{The Hohokam crushers as ballgame handstones?}

If our hypothesis is correct, it fits with both our and Taube and Zender's theories, at least in the Mesoamerican context. But it remains to explain the presence of at least 14/15 handstones in Arizona. As presented above, the Hohokam handstones fit almost perfectly with our definition, in terms of morphology, 
size, weight and chronology. They have been discovered only in the area where the presence of ballcourts is well documented, and share the same lack of interpretative function, even if we cannot totally discard the hypothesis of other use, and even of reuse of old artefacts. One Hohokam handstone was probably made out of a former metate (Table $\left.1, \mathrm{n}^{\circ} 6\right)$. In this case, a wellidentified artefact has been purposely reworked to acquire a new significance. Following Borhegyi's and Wilcox and Sternberg's interpretations, they have been considered as ballgame-related artefacts. From the lack of evidence of their use in the game proper, and from the available iconographic comparative data, we can now propose that they were rather associated with post-game rituals, as were their Mesoamerican counterparts.

As far as we know, boxing is not documented among the Hohokam, or more generally any other civilization in the USA (Voorhies 2017). Neither are sacrificial rituals, such as decapitation. The only potential example of decapitation associated with ballcourts in northern Mexico comes from Paquime, where a skull was discovered in an offering at the centre of the main ballcourt (DiPeso 1974). But it postdates the Hohokam ballcourts by several centuries.

We may then surmise that the Hohokam handstones were ballgame-related items, in the specific context of agricultural fertility and associated rituals. The complex and very elaborate Hohokam irrigation system is contemporary with the ballgame tradition, and both features are deeply intricate. As a matter of fact, they share numerous political and economic implications (see, e.g., Abbott, Smith, and Gallaga 2007). Could we suppose that the Hohokam handstones were somewhat related to agricultural fertility rituals, dissociated from human sacrifice? It remains to explain how such similar sets of unusual, nonfunctional artefacts may have played similar ritual functions in such distant areas, Mesoamerica and the Southwest. Let us recall that the westernmost example of a Mesoamerican handstone comes from Teotihuacan, more than $2000 \mathrm{~km}$ south of Arizona. And while ballcourts have now been registered continuously from central Mexico to the Southwest, we still lack the necessary data to explain the transmission of the game and its associated ritual paraphernalia.

We can only hope that interested readers who may know of a few more examples of these manoplas could help us to shed further light on this topic. *

* Manuscrit reçu en octobre 2019, accepté pour publication en juin 2020. 


\section{References cited}

BAUdez Claude F.

2011 “Las batallas rituales en Mesoamérica, parte 1," Arqueología Mexicana, 112, p. 20-29.

2012 “Las batallas rituales en Mesoamérica, parte 2," Arqueología Mexicana, 113, p. 18-29.

BERNAL Ignacio

1968 “The ballplayers of Dainzú,” Archaeology, 21, p. 246-251.

Аввотт David R., Alexa M. Smith, and Emiliano Gallaga

2007 "Ballcourts and ceramics: the case for Hohokam marketplaces in the Arizona Desert," American Antiquity, 72, p. 461-484.

Borhegyi Stephan F. de

1961 "Ball game hand-stones and ball-game gloves," in Samuel K. Lothrop (eds.), Essays in Pre-Columbian Art and Archaeology, Harvard University Press, Cambridge, p. 100-125.

1964 "Pre-columbian ball-game handstones: rejoinder to clune," American Antiquity, 39 (1), p. 84-86.

1967 "Piedras semiesféricas con asas para el juego de pelota y manoplas en Mesoamérica: una posible alternativa para su función," Estudios de Cultura Maya, 6, p. 215-219.

1980 "The Rubber Ball Game of Ancient America," Lore, Milwaukee Public Museum Quarterly, 13 (2), p. 44-53.

Castillo Peña Patricia

1995 La expresión simbólica del Tajín, INAH (Científica, 306), México.

Clune Francis J.

1963 "Borhegyi's interpretation of certain Mesoamerican objects as ballgame handstones," American Antiquity, 29, p. 241-242.

Covarrubias Miguel

1957 Indian Art of Mexico and Central America, Alfred A. Knopf, New York.

Cuevas Berta

1970 Carrizal, un sitio Preclásico, Tesis de maestría, Escuela de Antropología, Universidad Veracruzana, Xalapa.

De la Garza Mercedes and Ana Luisa IzQuierdo

1992 "El juego de los dioses y el juego de los hombres. Simbolismo y caracter ritual del juego de pelota entre los mayas," in María Teresa Uriarte (ed.), El juego de pelota en Mesoamérica. Raíces y supervivencia, Siglo XXI (América Nuestra, 39), México, p. 335-353.

DiPeso Charles C.

1974 Casas Grandes. A Fallen Trading Center of the Gran Chichimeca, vols. 1-3, Amerind Foundation, Dragoon/Northland Press, Flagstaff.

Dunkelman Arthur (ed.)

2007 The Jay I. Kislak Collection at the Library of Congress, Library of Congress, Washington (DC). 
Dutton, Bertha P. and Hulda R. HobBs

1943 Excavations at Tajumulco, Guatemala, University of New Mexico Press (Monographs of the School of American Research), Santa Fe.

ЕкноLм Gordon R.

1946 "The probable use of Mexican stone yokes," American Anthropologist, 48, p. 593-606.

El juego de pelota: una tradición prehispánica viva

1986 Museo Nacional de Antropología/Sociedad de Amigos del Museo/INAH, México. El juego de pelota en el México precolombino, y su pervivencia en la actualidad

1992 Museu Etnologic/Fundació Folch/Ajuntament de Barcelona, Barcelona.

FEWKES Jesse W.

1907 "Certain Antiquities of Eastern Mexico," in 25th Annual Report, Bureau of American Ethnology, Washington (DC), p. 221-284.

1912 "Casa Grande, Arizona," in William Henry Holmes, Twenty-eighth annual Report of the Bureau of American Ethnology to the Secretary of the Smithsonian Institution, 1906-1907, U.S. G.P.O., Washington (DC), p. 25-280.

Follett Prescott H. F.

1932 War and Weapons of the Maya, Tulane University Press (Middle American Research Institute, 4), New Orleans, p. 373-410.

HAURY Emil W.

1945 "The Excavations of Los Muertos and Neighbouring Ruins in the Salt River Valley, Southern Arizona," Southwestern Journal of Anthropology, 1 (1), p. 55-74.

Hellmuth Nicholas

1996 All the ballplayer decapitation stelae of Aparicio, Vega de Alatorre, Veracruz, Mexico, Foundation for Latin American Archaeological Research, Cocoa, Florida.

Joyce Thomas A.

1933 "The Pottery-whistle Figurines of Lubaantun," Royal Anthropological Institute of Great Britain and Ireland, Journal, 63, p. 15-25.

KUROSAKI Maekawa Mitsuru

2006 Estudio sobre los yugos, Undergraduate Thesis in Anthropology, ENAH, México. LeE Thomas A. Jr.

1969 The Artifacts of Chiapa de Corzo, Chiapas, Mexico, Brigham Young University (New World Archaeological Foundation Papers, 26), Provo.

LeYenAar Ted J. J.

1997 Ulama, Ballgame from the Olmecs to the Aztecs, Musée Olympique/Comité international olympique/Bertelsmann, Lausanne.

LeyenaAr Ted J. J. and Lee A. Parsons

1988 Ulama. The Ballgame of the Mayas and Aztecs, 2000 BC-AD 2000, Spruyt, Van Mantgen \& De Does, Leiden.

Lothrop Samuel K.

1936 Zacualpa, a Study of Ancient Quiche Artefacts, Carnegie Institution of Washington (Pub., 472), Washington (DC).

MANZANiLla Linda (coord.)

1993 Anatomía de un conjunto residencial teotihuacano en Oztoyahualco, Tomo 1. Las excavaciones, Instituto de Investigaciones Antropológicas, UNAM, México. 
MiLLER Mary Ellen

1989 "The ballgame," Record of the Art Museum, Princeton University, 48 (2), p. 22-31.

Moholy-NaGy Hattula

2011 The Artifacts of Tikal-Utilitarian Artifacts and Unworked Material. Tikal Reports $\mathrm{n}^{\circ} 27 \mathrm{~B}$, University of Pennsylvania Museum of Archaeology and Anthropology, Philadelphia.

MOOREHEAD Warren K.

1906 A narrative of exploration in New Mexico, Arizona, Indiana, etc., Philllips Andover Academy Department of Archaeology (Bulletin, 3), Andover.

ORR Heather

2003 "Stone balls and masked men: ballgame as combat ritual, Dainzú, Oaxaca," Ancient Mesoamerica, 5, p. 73-104.

PARSONS Lee A.

1978 "The peripherical coastal lowlands and the middle classic lowlands," in Esther Pasztory (ed.), Middle Classic Mesoamerica AD 400-700, Columbia University, New York, p. 25-34.

PIÑa CHAN Román

1968 Sports et jeux dans l'art précolombien du Mexique, Musée Cernuschi, Paris. Roose Ninon

2006 Le complexe des haches, jougs et palmes en Mésoamérique, Ph.D. Thesis, Archaeology, Prehistory, Ethnology, Anthropology, université Paris 1 Panthéon-Sorbonne, Paris.

ScotT John F.

1978 "Los primeros 'yugos' veracruzanos," Anales del Instituto de Investigaciones Estéticas, 13, p. 25-48.

TALADOIRE Eric

2003 "La pelota mixteca and the Palangana Ballcourts. A prehispanic ballgame and its possible architectural context," Ancient Mesoamerica, 14, p. 319-342.

2016 "Manoplas, candados, rieles y otros objetos inusuales asociados a los juegos de pelota," Arqueología, Revista de la coordinación de Arqueología, INAH, México, 51, p. 198-225.

TAuBE Karl

2004 Olmec Art at Dumbarton Oaks, Dumbarton Oaks Research Library and Collections (Precolumbian Art at Dumbarton Oaks, 2), Washington (DC).

2017 "The Ballgame, Boxing and Ritual Blood in Ancient America," in Colin Renfrew, Iain Morley, and Michael J. Boyd (eds.), Ritual, Play and Belief in Evolution and Early Human Societies, Cambridge University Press, Cambridge, p. 264-301.

TAUBE Karl and Marc ZENDER

2009 "American Gladiators: Ritual Boxing in Ancient Mesoamerica," in Heather S. Orr and Rex Koontz (eds.), Blood and Beauty. Organized Violence in the Art and Archaeology of Mesoamerica and Central America, Cotsen Institute of Archaeology Press, UCLA, Los Angeles, p. 161-220. 
THOMPSON John Eric

1941 “Yokes or ball game belts?” American Antiquity, 6 (2), p. 320-326.

1943 "A figurine whistle representing a ballgame player," Notes on Middle American Archaeology and Ethnology, 1 (25), p. 160-162.

1948 An Archaeological Reconnaissance in the Cotzumalhuapa Region, Escuintla, Guatemala, Carnegie Institution of Washington (Contributions to American anthropology and history, 44), Washington (DC).

Tozzer Alfred M.

1957 Chichen Itza and its Cenote of Sacrifice. A Comparative Study of Contemporaneous Maya and Toltec, Peabody Museum-Harvard University (Memoirs, XI, XII), Cambridge.

VoORHIEs Barbara (ed.)

2017 Prehistoric games of North American Indians. Subarctic to Mesoamerica, University of Utah Press, Salt Lake City.

Whittington E. Michael (ed.)

2001 The Sport of Life and Death. The Mesoamerican Ballgame, Thames and Hudson, New York.

WILCOX David R.

1986 “The Tepiman connection: a model of Mesoamerican-Southwestern interaction," in Frances Joan Mathien and Randall H. McGuire (eds.), Ripples in the Chichimec sea : new considerations of southwestern-mesoamerican interactions, Southern Illinois University Press, Carbondale, p. 135-153.

Wilcox David R. and Charles SternBerg

1983 Hohokam Ball Courts and their Interpretation, Cultural Resources Management Division, Arizona State Museum (Archaeological Series Monograph, 160), Tucson.

WiLLiAMs Eduardo

1992 Las piedras sagradas. Escultura prehispánica del Occidente de México, El Colegio de Michoacán, Zamora. 
